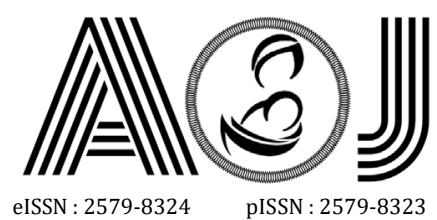

eISSN : 2579-8324
pISSN : 2579-8323

\title{
RESEARCH
}

\section{Correlation of Tumor Vascularization Using Spectral Pulse Wave Doppler with Neoadjuvant Chemotherapy Response in IB2 and IIA2 stages of Cervical Cancer}

\author{
Syamel Muhammad ${ }^{1}$, Nindya Rahmadita ${ }^{2}$ \\ Affiliations: 1. Sub Division of Gynecological Oncology, Obstetrics and Gynecology Department, \\ Faculty of Medicine, Andalas University, Dr. M. Djamil Central General Hospital Padang; 2. Medical \\ Student, Faculty of Medicine, Andalas University, Dr. M. Djamil Central General Hospital Padang \\ Correspondence: Syamel Muhammad, email: syamelmuhammad@med.unand.ac.id, Hp: 08126648977
}

\begin{abstract}
Cervical cancer is an abnormal growth or cell changes in the cervical wall, which is the $4^{\text {th }}$ rank in the most common cancer among female and the $2^{\text {nd }}$ most common cancer in female aged fifteen until fourty four years old worldwide. Neovascularization becomes an important step in determining the onset and progressive cancer. Neoadjuvant chemotherapy has been evaluated as a treatment strategy in the stages IB2 and IIA2. The use of chemotherapy drug becomes more effective in adjacent and regular vascularization, and it allows the blood flow to the organs more quickly. This study aims to determine the correlation of tumor vascularization using Spectral Pulse Wave Doppler with neoadjuvant chemotherapy response in IB2 and IIA2 stages of cervical cancer. This research is a cohort analytic study which involves thirty six of patient in IB2 and IIA2 stages. The sampling is selected by using consecutive sampling technique. The data includes the result of ultrasound examination and were analyzed by using the Chi-square test. The results of the research on good and poor tumor vascularization had a good response to thirty of patient (83.3\%) who were given neoadjuvant chemotherapy. There was no significant effect between tumor vascularization using Spectral Pulse Wave Doppler to the responses of neoadjuvant chemotherapy in IB2 and IIA2 stages of cervical cancer. Keywords: tumor vascularization using Spectral Pulse Wave Doppler, responses of neoadjuvant chemotherapy, IB2 and IIA2 stages of cervical cancer
\end{abstract}

\section{INTRODUCTION}

Cervical cancer is defined as an abnormal growth or cell changes in the cervical wall. Cervical cancer ranks as the fourth most common cancer among female and second most common cancers in female aged between $15-44$ years worldwide. There were 527,624 new cases worldwide and 265,672 deaths caused by cervical cancer in 2012. The incidence of cervical cancer in 2012 showed that there were 284,823 new cases recorded in the Asian region and 50,566 new cases recorded in the region of Southeast Asia. Southeast Asia ranks in the third in the number of cases of cervical cancer in the Asian region, with Indonesia occupying the tenth spot in incidence of cervical cancer in the Asian region at 17,3\% per 100,000 female per year. ${ }^{1}$ 


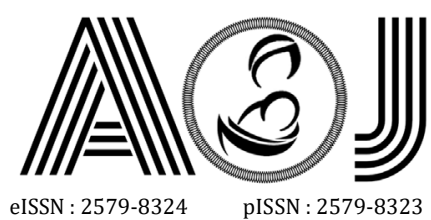

eISSN : 2579-8324
pISSN : 2579-8323
ANDALAS OBSTETRICS AND GYNECOLOGY JOURNAL

Alamat Korespondensi:

Ruang Redaksi Andalas Obstetrics and Gynecology Journal, Lantai 3 PPDS Obstetri dan Ginekologi Universitas Andalas, RSUP DR. M. Djamil Padang, Jl. Perintis Kemerdekaan Padang, Sumatera Barat 25127

Website:

http://jurnalobgin.fk.unand.ac.id/index.php/JOE

The total population of cervical cancer cases in West Sumatra in 2013 was 2,285 cases and was ranked eight position throughout Indonesia. ${ }^{2}$ According to the research on the description of risk factors for cervical cancer at Dr. M. Djamil General Hospital, Padang, there was an increase in the incidence of cervical cancer, with 37 cases in 2009, 58 cases in 2010 and 2011, 42 cases in 2012, 251 cases in 2014, 214 cases in 2015, 151 cases in 2016, and 287 cases from January to September $2017 .^{3}$

Management of cervical cancer patients is distinghuished based on the classification of the International Federation of Gynecology and Obstetrics (FIGO). Patients with IB1 and IIA stages of cervical cancer with tumors smaller than $4 \mathrm{~cm}$ are given radical hysterectomy with pelvic lymphadenectomy or radiation therapy, while patients with stages IB2 and IIA with tumors greater than $4 \mathrm{~cm}$ are treated with radiation therapy and cisplatin as chemotherapy, hysterectomy followed by adjuvant radiation therapy or cisplatin chemotherapy given after hysterectomy. ${ }^{4}$ The treatment choice for stages IIB - IIIB is chemoradiothreapy with additional neoadjuvant chemotherapy followed by surgery or radiaton therapy. Stage IVA patients can undergo chemotherapy and pelvic exenteration. ${ }^{5}$ The use of neoadjuvant chemotherapy is believed to reduce tumor size, increase tumor vascularization, reduce the number of hypoxic cells, increase radiosensitivity to tumors, and suppress the course of metastases by eliminating metastasized lesions. ${ }^{6}$, On the other hand, the use of neoadjuvant chemotherapy is receiving attention because patients who do not respond to chemotherapy can have their curative treatment plans delayed, thus it is important to find markers that can determine the response of chemotherapy for patients. ${ }^{7}$

Sardi's 1997 study, using Randomized Clinical Trial (RCT) of neoadjuvant chemotherapy in IB squamous cell carcinoma patients, compared results between patients who used neoadjuvant chemotherapy before surgery with those who only used surgery as treatment. The results of this study indicate that management using neoadjuvant chemotherapy before surgery has a higher rate of completion of surgery in patients with tumor diameters greater than $4 \mathrm{~cm}$. This shows that the use of neoadjuvant chemotherapy can significantly prolong survival by reducing the factor of poor pathological prognosis. ${ }^{8}$ Similar results were obtained in the study of Loizzi et al. in 2018, out of 23 patients using neoadjuvant chemotherapy as many as 20 patients (87\%) responded well to chemotherapy, receiving a complete response of $17 \%$ and partial response of $70 \%$, which included progressive disease by $9 \%$ and stable disesase by $4 \% .{ }^{9}$ From the results of existing studies, it is necessary to do further research to prove the effectiveness of the use of neoadjuvant chemotherapy in cervical cancer therapy. ${ }^{10}$

The formation of new blood vessel or neovascularization is an important step in determining the onset and progression of cancer in humans. ${ }^{11}$ Tumor vascularization in cervical cancer can be assessed in vivo with Trasvaginal Colour Doppler (TVCD). ${ }^{12}$ In one study, 97 patients with cervical tumors could be evaluated with a 3D-Power Doppler Ultrasound 


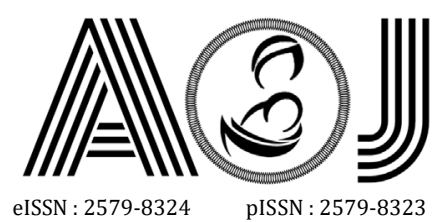

eISSN : 2579-8324
pISSN : 2579-8323
ANDALAS OBSTETRICS AND GYNECOLOGY JOURNAL

Alamat Korespondensi:

Ruang Redaksi Andalas Obstetrics and Gynecology Journal, Lantai 3 PPDS Obstetri dan Ginekologi Universitas Andalas, RSUP DR. M. Djamil Padang, Jl. Perintis Kemerdekaan Padang, Sumatera Barat 25127

http://jurnalobgin.fk.unand.ac.id/index.php/JOE

where Vascularization Index (VI), Flow Index (FI), and Vascularization Flow Index (VFI) patients with tumors could be detected significantly higher than normal cervix or cervix that has undergone prior conization. Several studies have focused on changes in this index before and during chemotherapy. One study with 30 cervical cancer patients compared with 35 normal female showed that VI adn VFI were significantly higher in the cervical cancer group, and patients showed a significant reduction after neoadjuvant chemotherapy session. The use of VI was also assessed in predicting the response of cervical carcinoma to neoadjuvant chemotherapy. ${ }^{13}$ Study shows the use of chemotherapy drugs is more effective in adjacent and regular blood vessels, allowing blood flow to these organs faster. ${ }^{14}$

\section{METHOD}

This research is an analytic cohort study that examines the correlation of tumor vascularization using Spectral Pulse Wave Doppler with neoadjuvant chemotherapy response in IB2 and IIA2 stages of cervical cancer. The independent variable in this study is tumor vascularization using Spectral Pulse Wave Doppler and the dependent variable in this study is the neoadjuvant chemotherapy response.

This study was carried out in the Gynecology ward of Department Obstetrics and Gynecology Dr. M. Djamil General Hospital Padang from May 2018 - March 2019. The target population is patients with stage IB2 and IIA2 cervical cancer in Dr. M. Djamil General Hospital Padang who underwent neoadjuvant chemotherapy.

Samples of this study were cervical cancer patients who met the inclusion and exclusion criteria. Inclusion criteria: patients with a diagnosis of IB2 and IIA2 cervical cancer, who underwent neoadjuvant chemotherapy, and were willing to take part in the study. Exclusion criteria: patients that transrectal ultrasound examination cannot be done either because of hemorrhoids, perianal pain, or anal stenosis, and who can't continue as a study sample (dropped out).

The sample size for the Doppler variable is 16.81 by adding the possibility of a $10 \%$ drop out rate to 18 for each group, with 36 total sample. ${ }^{15,16}$ The selection of sample is done by non-probability sampling technique that is consecutive sampling from the population of IB2 and IIA2 cervical cancer patients in Dr. M. Djamil General Hospital Padang who underwent neoadjuvant chemotherapy.

Data were analyzed statistically based on variables assessed using a computerized system that is univariate and bivariate analysis. Univariate analysis aims to explain the characteristics of each of the variables studied, namely age, stage, histopathology, hemoglobin levels, tumor size, and tumor valume. The bivariate analysis aims to see the effect between the two variable in the study, namely tumor vascularization using Spectral Pulse 


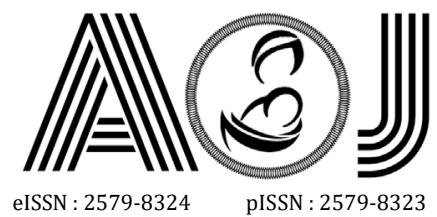

eISSN : 2579-8324
pISSN : 2579-8323

Ruang Redaksi Andalas Obstetrics and Gynecology Journal, Lantai 3 PPDS Obstetri dan Ginekologi Universitas Andalas, RSUP DR. M. Djamil Padang, Jl. Perintis Kemerdekaan Padang, Sumatera Barat 25127

Wave Doppler and neoadjuvant chemotherapy responses. In this study bivariate analysis was performed by Chi-square statistical test with Statistical Program for Social Science (SPSS).

\section{RESULT}

This research was carried out in the Department Obstetrics and Gynecology Dr. M. Djamil General Hospital Padang. The target population of this study was IB2 and IIA2 stages of cervical cancer patients at Dr. M. Djamil General Hospital Padang who underwent neoadjuvant chemotherapy. Subjects were 36 people who met the inclusion criteria and exclusion criteria for conducting the study. The study subjects were taken by consecutive sampling.

Tumor vascularizaion is determined using Spectral Pulse Wave Doppler, namely by transrectal ultrasonography before undergoing neoadjuvant chemotherapy which is categorized as good vascularization and poor vascularization. Neoadjuvant chemotherapy response is measured according to RECIST 1.1 criteria where the results of neoadjuvant chemotherapy response measurements are categorized as good response and poor response. The research data is then computerized.

Frequency Distribution of IB2 and IIA2 Stages of Cervical Cancer Patients Based on Tumor Vascularization using Spectral Pulse Wave Doppler

Table 1. Frequency Distribution of IB2 and IIA2 Stages of Cervical Cancer Patients Based on Tumor Vascularization using Spectral Pulse Wave Doppler

\begin{tabular}{|c|c|c|}
\hline \multirow{2}{*}{ Characteristics } & \multicolumn{2}{|c|}{ Vascularization } \\
\hline & Good (n=18) & Poor $(n=18)$ \\
\hline \multicolumn{3}{|l|}{ Age $f(\%)$} \\
\hline $20-30$ & $0(0)$ & $0(0)$ \\
\hline$>30-40$ & $4(11.1)$ & $1(2.8)$ \\
\hline$>40-50$ & $5(13.9)$ & $8(22.2)$ \\
\hline$>50$ & $9(25)$ & $9(25)$ \\
\hline \multicolumn{3}{|l|}{ Stage $\mathrm{f}(\%)$} \\
\hline IB2 & $8(22.2)$ & $10(27.8)$ \\
\hline IIA2 & $10(27.8)$ & $8(22.2)$ \\
\hline \multicolumn{3}{|l|}{ Histopathology type f (\%) } \\
\hline Squamous cell carcinoma & $13(36.1)$ & $13(36.1)$ \\
\hline Adenocarcinoma & $3(8.3)$ & $4(11.1)$ \\
\hline Lainnya & $2(5.6)$ & $1(2.8)$ \\
\hline \multicolumn{3}{|l|}{ Hemoglobin levels (gr/dl) f(\%) } \\
\hline $10-12$ & $13(36.1)$ & 14 (38.9) \\
\hline$>12$ & $5(13.9)$ & $4(11.1)$ \\
\hline \multicolumn{3}{|l|}{ Tumor size $(\mathrm{cm}) \mathrm{f}(\%)$} \\
\hline $4-6$ & $11(30.6)$ & $10(27.8)$ \\
\hline$>6$ & $7(19.4)$ & $8(22.2)$ \\
\hline
\end{tabular}




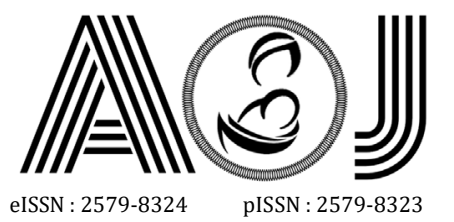

ANDALAS OBSTETRICS AND GYNECOLOGY JOURNAL

Alamat Korespondensi:

Ruang Redaksi Andalas Obstetrics and Gynecology Journal, Lantai 3 PPDS Obstetri dan Ginekologi Universitas Andalas, RSUP DR. M. Djamil Padang, Jl. Perintis Kemerdekaan Padang, Sumatera Barat 25127

Website:

http://jurnalobgin.fk.unand.ac.id/index.php/JOE

\begin{tabular}{lcc}
\hline Tumor Volume $\left(\mathrm{cm}^{3}\right)$ & & \\
Begining & & \\
Mean & 70.72 & 48.29 \\
Median & 50.49 & 35.55 \\
SD & 66.71 & 35.31 \\
Minimum & 16.72 & 10.38 \\
Maximum & 255.02 & 134.50 \\
End & & \\
Mean & 10.38 & 22.92 \\
Median & 6.06 & 5.88 \\
SD & 10.37 & 54.03 \\
Minimum & 0.93 & 0.77 \\
Maximum & 37.54 & 235.65 \\
\hline
\end{tabular}

Based on table 1, it can be seen that the distribution of patient characteristics in tumor vascularization is good, it is mostly found at age $>50$ years which is $25 \%$, while for the stage the most in stage IIA2 is $27.8 \%$, for histopathological type, there are many squamous cell carcinoma $36.1 \%$, with a dominant hemoglobin level of $10-12 \mathrm{gr} / \mathrm{dl}$ of $36.1 \%$, and the most tumor size was found with a size of $4-6 \mathrm{~cm}$ which is $30.6 \%$, as well as an average reduction in tumor volume from $70.72 \mathrm{~cm}^{3}$ to $10.38 \mathrm{~cm}^{3}$ or around $74.40 \%$.

The distribution of patients characteristics in poor vascularization was found at $>50$ years of age at $25 \%$, for the most cancer stage at IB2 stage which was $27.8 \%$, the most histopathological type was squamous cell carcinoma with $36.1 \%$, with hemoglobin levels dominant $10-12 \mathrm{gr} / \mathrm{dl}$ of $38.9 \%$, and tumor size of $4-6 \mathrm{~cm}$ by $27.8 \%$, and there was a decrease in the average tumor volume from $48.29 \mathrm{~cm}^{3}$ to $22.99 \mathrm{~cm}^{3}$ or about $35.62 \%$.

Analysis of the Correlation between Tumor Vascularization using Spectral Pulse Wave Doppler with Neoadjuvant Chemotherapy Response in IB2 and IIA2 Stages of Cervical Patients

Table 2. Analysis of the Correlation between Tumor Vascularization using Spectral Pulse Wave Doppler with Neoadjuvant Chemotherapy Response in IB2 and IIA2 Stages of Cervical Patients

\begin{tabular}{|c|c|c|c|c|c|c|}
\hline \multirow{3}{*}{$\begin{array}{c}\text { Spectral Pulse Wave } \\
\text { Doppler }\end{array}$} & \multicolumn{4}{|c|}{ Neoadjuvant Chemotherapy Response } & \multirow{3}{*}{ Total } & \multirow{3}{*}{$p$-value } \\
\hline & \multicolumn{2}{|c|}{ Good } & \multicolumn{2}{|c|}{ Poor } & & \\
\hline & f & $\%$ & f & $\%$ & & \\
\hline Good Vascularization & 16 & 88.9 & 2 & 11.1 & $18(100 \%)$ & \\
\hline Poor Vascularization & 14 & 77.8 & 4 & 22.2 & $18(100 \%)$ & 0.658 \\
\hline Total & 30 & 83.3 & 6 & 16.7 & $36(100 \%)$ & \\
\hline
\end{tabular}

Table 2 shows the correlation of tumor vascularization using Spectral Pulse Wave Doppler with neoadjuvant chemotherapy response. The results obtained are good tumor vascularization which will show a good chemotherapy response result of $88.9 \%$ and poor 


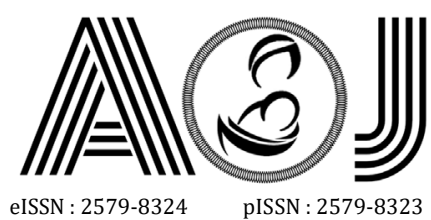

eISSN : 2579-8324
pISSN : 2579-8323
ANDALAS OBSTETRICS AND GYNECOLOGY JOURNAL

Alamat Korespondensi:

Ruang Redaksi Andalas Obstetrics and Gynecology Journal, Lantai 3 PPDS Obstetri dan Ginekologi Universitas Andalas, RSUP DR. M. Djamil Padang, Jl. Perintis Kemerdekaan Padang, Sumatera Barat 25127

Website:

http://jurnalobgin.fk.unand.ac.id/index.php/JOE

chemotherapy response $11.1 \%$. Poor tumor vascularization will show a good chemotherapy result of $77.8 \%$ and poor chemotherapy response of $22.2 \%$. Statistical test results with chisquare test obtained $p$ value $=0.658,(p>0.05)$ it can be concluded that there is no significant correlation between tumor vasculariation with neoadjuvant chemotherapy response.

\section{DISCUSSION}

Neovascularization is an important step in determining the onset and progression of cancer, which is involved in tumor growth, invasion, metastasis, and chemotherapy resistance. Vascularization assessment of tumors can be a way to predict tumor aggressiveness and can be used as a marker of susceptibility to antiangiogenic treatment. ${ }^{17}$ Study found the use of chemotherapy drugs is more effective in adjacent and regular blood vessels so as to allow blood flow to these organs fasters. ${ }^{14}$ Several studies have found that angiogenesis is an independent prognostic factor in cervical cancer and functions in predicting recurrence. ${ }^{18}$ Tumors with dense consistency in developing require new vascular to supply blood. This vascularization, also known as neovascularization, is derived from normal blood vessel tissue that has been formed previously through the process of angiogenesis, but this neovascularization can be formed more slowly when compared to the progression or growth of the tumor itself so that the new vascularizatoin cannot meet the oxygenation and nutrient requirements of the cell and cause hypoxia. It is therefore found that, good vascularization will have a better response to chemoradiation than tumors with poor or minimal vascularization. ${ }^{19}$

Based on research that has been done on 36 IB2 and IIA2 stages of cervical cancer patients undergoing neoadjuvant chemotherapy showed that there was no significant correlation between tumor vascularization with neoadjuvant chemotherapy response $(p=$ 0.658). The results of this study has found that the good and poor tumor vascularization both gave a good therapeutic response after neoadjuvant chemotherapy. The results of this study are in line with research conducted by Muhammad et al. in 2017 obtained from 58 patients with cervical cancer, 46 patients had a good clinical response after radiation therapy was given by 27 patients $(58.7 \%)$ with good vascularization and patients with poor vascularization were 19 patients (41.3\%). ${ }^{19}$ Based on the results of the study of Mangla and Singla (2015), of 56 cervical cancer patients, $58 \%$ patients had a complete response, $32 \%$ of patients had a partial response and $10 \%$ of patients did not response to the chemotherapy. From these results there's an increase of value of Resistive Index (RI) and Pulsatality Index (PI) significantly increased in patients with complete response while in patients with partial response were less significant and in patients with no response to chemotherapy there was no change in PI and RI values. ${ }^{12}$ In the study of Greco et al. of 14 patients, there was an increase in RI and PI 


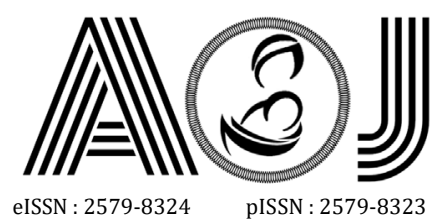

eISSN : 2579-8324
pISSN : 2579-8323

in 10 patients who had good responses to chemotherapy, while 4 other patients who had poor responses found no difference in RI and PI values after chemotherapy. ${ }^{20}$

According to Zhu et al. in seeing the Pre-operative Radiochemotherapy (PRCT) response to tumor vacularization using VEGF and HIF-1 $\alpha$ biomarkers, the value of VEGF and HIF-1 $\alpha$ before PRCT were significantly higher than after PRCT. The results of this study also obtained from 43 IB2 and IIA2 stages of cervical cancer patients as many as 35 patients had a good therapeutic response (81.39\%) consisting of 5 patients with complete responses found negative VEGF and HIF-1 $\alpha$ values and 30 patients with partial response found VEGF and HIF$1 \alpha$ values of $70 \%$ and $63.33 \%$ after PCRT. ${ }^{21}$ According to Chen et al. of the 12 patients who responded well to neoadjuvant chemotherapy, tumor size decreased from $21.33 \pm 28 \mathrm{~cm}^{2}$ to $5.71 \pm 1.57 \mathrm{~cm}^{2}$, and a decrease in Power Doppler Vascularity Index (PDVI) was found before administering neoadjuvant chemotherapy $12.28 \pm 7.06 \%$ to $9.3 \pm 5.4 \%$ after administration of neoadjuvant chemotherapy compared with patients who did not respond to neadjuvant chemotherapy obtained high PDVI values. ${ }^{22}$

In this study, although there was no significant correlation between tumor vascularization and neoadjuvant chemotherapy responses, a significant reduction in mean tumor volume in good tumor vascularization from $70.72 \mathrm{~cm}^{3}$ to $10.38 \mathrm{~cm}^{3}$ or about $74.40 \%$, while for poor vascularization, the average tumor volume decreased from $48.29 \mathrm{~cm}^{3}$ to $22.92 \mathrm{~cm}^{3}$ or about $35.62 \%$. Based on this study also found two patients with good vascularization but had a poor therapeutic response, this could be due to one patient having a histopathologial type of adenocarcinoma who had a worse prognosis due to having a less sensitive nature to therapy and often associated with previous disease metastases. ${ }^{23}$ One other patients was not affected by the factors that exist, the decrease in therapeutic response could be due to neovascularization of the tumor itself. Neovascularization itself can reduce the delivery of drugs to tumors, this happens because of the structure and function neovascularization is abnormal and immature and are easily broken. Unlike normal blood vessels, neovascularization has smaller diameters, different vascular densities, high permeability to larger molecules and the same microvascular and interstitial pressures, this causes a gradient pressure in the blood flow of the tumor which can cause hypoxia and disruption of supply to the target cell. This can also interfere with the delivery of therapeutic drugs and make tumor cells resistant to treatment, thus the decrease in effectiveness of chemotherapy. ${ }^{24}$

The use of better chemotherapy drugs can also improve the results of neoadjuvant chemotherapy. Based on study conducted by Santoso and Askandar, there were significant differences in the success of operablity in patients with cervical cancer with histopathological type squamous cell carcinoma given paclitaxel and carboplatin chemotherapy with the administration of cisplatin, vincristine, and bleomycin chemotherapy. The results of this study 


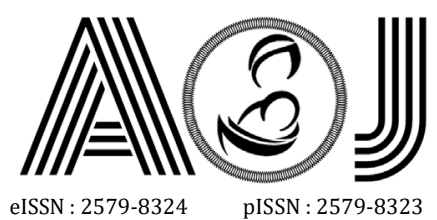

eISSN : 2579-8324
pISSN : 2579-8323

Ruang Redaksi Andalas Obstetrics and Gynecology Journal, Lantai 3 PPDS Obstetri dan Ginekologi Universitas Andalas, RSUP DR. M. Djamil Padang, Jl. Perintis Kemerdekaan Padang, Sumatera Barat 25127

indicate that the administration of chemotherapy paclitaxel and carboplatin gave operability success of $22.4 \%$, while the administration of chemotherapy chisplatin, vincristine, and bleomycin gave a success rate of $14.6 \%$. The successful combination of paclitaxel and arbolatin is due to having high cytotoxic activity as a single agent. ${ }^{25}$ Carboplatin is known to having milder side effects compared to cisplatin, with the most common side effects with chemotherapy using cisplatin are ototoxicity (23 - 50\%), peripheral neuropathy $(60 \%)$, myelosuppression $(<5 \%)$, and nephrotoxicity $(20-41 \%)$, while chemotherapy using carboplatin side effects are myelosuppresion (20-90\%), neurotoxicity with rare cases $(6 \%)$, and nephrotoxicity (usually reported in patients with impaired kidney functions). ${ }^{26}$

\section{CONCLUSION}

Based on the results of this study, it was concluded that there were no correlation between tumor vascularization using spectral pulse wave doppler and neoadjuvant chemotherapy responses in IB2 and IIA2 stages of cervical cancer patients.

\section{SUGESSTION}

Patients with stage IB2 and IIA2 cervical cancer can be given neoadjuvant chemotherapy as an alternative therapy. Further research with better designs on other factors that influence neoadjuvant chemotherapy responses such as the degree of differentiation in tumors and other angiogenesis factors.

\section{ACKNOWLEDGEMENTS}

Sincerest gratitude to all parties involved in this study for their guidance, direction, and motivation provided during the course of this study. We would like to extend our gratitude to Dr. M. Djamil General Hospital Padang for allowing this study to take place.

\section{REFERENCES}

1. Bruni L, Barrionuevo-Rosas L, Alberto G, Serrano B, Mena M, Gómez D, et al. Human Papillomavirus and Related Diseases Report. ICO/IARC HPV Information Centre; 2017.

2. Kementrian Kesehatan RI. Situasi Penyakit Kanker. Riset Kesehatan Dasar. 2015.

3. Yanti YN. Gambaran Faktor Resiko Kejadian Kanker Serviks di RSUP Dr. M. Djamil Padang. Jurnal Kesehatan Andalas. 2018;3(1):1-17.

4. Deverakonda A, Gupta N. Diagnosis and treatment of cervical cancer: a review. J Nurs Heal Sci. 2016;2(3):1-11.

5. Marth C, Landoni F, Mahner S, McCormack M, Gonzalez-Martin A, Colombo N. Cervical cancer: ESMO Clinical Practice Guidelines for diagnosis, treatment and follow-up. Ann 
Oncol. 2017;28(4):72-83.

6. Lapresa M, Parma G, Portuesi R, Colombo N. Neoadjuvant chemotherapy in cervical cancer: An update. Expert Rev Anticancer Ther. 2015;15(10):1171-81.

7. González-Martín A, González-Cortijo L, Carballo N, Garcia JF, Lapuente F, Rojo A, et al. The current role of neoadjuvant chemotherapy in the management of cervical carcinoma. Gynecol Oncol. 2008;110:36-40.

8. Sardi JE, Giaroli A, Sananes C, Ferreira M, Soderini A, Bermudez A, et al. Long-Term Follow-up of the First Randomized Trial Using Neoadjuvant Chemotherapy in Stage Ib Squamous Carcinoma of the Cervix : The Final Results. Gynecol Oncol. 1997;67:61-9.

9. Loizzi V, Vecchio V Del, Crupano FM, Minicucci V, Fumarulo V V, Resta L, et al. A phase II study : dose-dense carboplatin and paclitaxel as neoadjuvant chemotherapy in locally advanced cervical cancer A phase II study: dose-dense carboplatin and paclitaxel as neoadjuvant chemotherapy in locally advanced cervical cancer. J Chemother. 2018;30(4):247-52.

10. Iwata T, Miyauchi A, Suga Y, Nishio H, Nakamura M, Ohno A, et al. Neoadjuvant chemotherapy for locally advanced cervical cancer. Chinese J Cancer Res. 2016;28(2):235-40.

11. Alldredge JK, Tewari KS. Clinical Trials of Antiangiogenesis Therapy in Recurrent/Persistent and Metastatic Cervical Cancer. Oncologist. 2016;21(5):576-85.

12. Mangla $M$, Singla D. Transvaginal colour Doppler ultrasound in predicting response to chemoradiation in patients with carcinoma of the cervix. South African J Gynaecol Oncol. 2015;7(2):68-71.

13. Belitsos P, Papoutsis D, Rodolakis A, Mesogitis S, Antsaklis A. Three-dimensional power Doppler ultrasound for the study of cervical cancer and precancerous lesions. Ultrasound Obstet Gynecol. 2012;40(5):576-81.

14. Onofrio AD, Gandolfi A. Chemotherapy of vascularised tumours: Role of vessel density and the effect of vascular "pruning". J Theor Biol. 2010;264(2):253.

15. Dahlan MS. Besar Sampel dan Cara Pengambilan Sampel dalam Penelitian Kedokteran dan Kesehatan. Edisi 3. Vol. 3, Salemba Medika. 2010. 46-60 p.

16. Qin J, Cheng X, Chen X, Zhang X, Lu W, Xie X. Value of three-dimensional power Doppler to predict clinical and histological response to neoadjuvant chemotherapy in locally advanced cervical carcinoma. Ultrasound Obs Gynecol. 2012;39(1):226-34.

17. Testa AC, Ferrandina G, Distefano M, Fruscella E, Mansueto D, Basso D, et al. Color Doppler velocimetry and three-dimensional color power angiography of cervical carcinoma. Ultrasound Obstet Gynecol. 2004;24(4):445-52.

18. Dodampahala SH, Jayakody SN, Gunathilake WCC, Rahubaddha AN, Dodampahala SK. Transvaginal Color Doppler in the Assessment of Cervical Carcinoma and Pre-Cancer : 
Evidence from a Case Control Study Using Colour Doppler Ultrasonography Pulsatility Index of Uterine Vasculature. Sci Res Publ. 2016;4(3):93-9.

19. Muhammad S, Suardi D, Tobing MDL. Hubungan gambaran spektral pulse wave doppler dengan respon klinis terapi radiasi eksternal pada kanker serviks stadium IIBIVA. Maj Kedokt Andalas. 2018;41(1):10-21.

20. Greco P, Cormio G, Vimercati A, Nacci G, Vagno G Di, Loverro G, et al. Transvarrinal color Doppler ultrasound for monitoring the response to neoadjuvant chemotherapy in advanced cervical cancer. Acta Obstet Gynecol Scand. 1997;76(2):169-72.

21. Zhu P, Ou Y, Dong Y, Xu P, Yuan L. Expression of VEGF and HIF-1 $\alpha$ in locally advanced cervical cancer: potential biomarkers for predicting preoperative radiochemotherapy sensitivity and prognosis. Onco Targets Ther. 2016;9:3031-7.

22. Chen C-A, Cheng W-F, Lee C-N, Su Y-N, Hsieh C-Y, Hsieh F-J. Power Doppler vascularity index for predicting the response of neoadjuvant chemotherapy in cervical carcinoma. Acta Obstet Gynecol Scand. 2004;83:591-7.

23. Couvreur K, Naert E, Jaeghere E De, Tummers P, Makar A, Visschere P De, et al. Neoadjuvant treatment of adenocarcinoma and squamous cell carcinoma of the cervix results in significantly different pathological complete response rates. 2018;1-10.

24. Nishida N, Yano H, Nishida T, Kamura T, Kojiro M. Angiogenesis in cancer. Vasc Health Risk Manag. 2006;2(3):213-9.

25. Santoso C, Askandar B. Keberhasilan Kemoterapi Neoajuvan Cisplatin-VincristineBleomycin dan Paclitaxel-. Maj Obstet Ginekol. 2011;19(3):1-11.

26. Fischetti M, Musella A, Di V, Giorgia D. Dose-Dense Neoadjuvant Chemotherapy plus Radical Surgery in Locally Advanced Cervical Cancer : A Phase II Study. 2015;103-10. 